\title{
Межславянские лексические заимствования в дипломатической корреспонденции Московского государства
}

\author{
ЛЮДМИЛА ГАРБУЛЬ \\ Romanų kalbų katedra, Užsienio kalbų institutas, Vilniaus universitetas, \\ Universiteto g. 5, LT-01513 Vilnius \\ E-mail: liudmila.garbul@flf.vu.lt \\ (Received: 12 January 2015; accepted: 27 March 2015)
}

\begin{abstract}
The article examines the origin of the following words found in the diplomatic correspondence of Muscovite Russia of the 17th century: взглядъ 'point of view; standpoint; opinion; appraisal' (мъти взглядъ 'consider, take into consideration'), выполняти 'implement, fulfil, carry out', высвобожсати 'free, liberate', дал(ь)ший 'further, subsequent', доведенье 'argument; proving, proof, substantiation', догажати, догодити 'please; oblige; play up to', додавати 'add to, give', доложити 'add to; supplement with', and допомогати 'help, assist, aid'. The paper retraces their further fate in Russian and other East Slavonic languages as well as in the Polish language. The author aims at proving that these intra-Slavonic derivates are inter-Slavonic lexical loanwords (Polonisms) in the Russian language. It is also stated that the word высвобожати probably is a loanword from the written language of the Grand Duchy of Lithuania in the Russian written language of the 17th century.

Keywords: inter-Slavonic language contacts, loanwords, etymology, the Grand Duchy of Lithuania, diplomatic correspondence
\end{abstract}

Как известно, межъязыковые контакты являются одним из факторов, стимулирующих развитие контактирующих языков и способствующих обогащению их словарного состава. Это касается всех языков, в том числе и славянских, ведь наблюдаемое в наше время и в более ранние периоды большое сходство этих языков лишь отчасти обусловлено их генетическим родством, в значительной же мере общность лексического состава славянских языков является следствием их культурного взаимодействия, которое не прервалось после распада праславянского единства (см. ЗолтАн 2014: 13).

Наше внимание на протяжении нескольких десятилетий привлекают польско-русские и - шире - польско-восточнославянские языковые контакты на уровне лексики. Начало польско-восточнославянских языковых контактов следует отнести к XIV-XV вв., наибольшей же интенсивности они достигают в XVI-XVII вв.

Занимаясь изучением польского влияния на русский приказный язык, в частности на документацию Посольского приказа первой половины XVII в., мы обнаружили значительное количество лексических полонизмов, бо́льшая часть которых проникла в русский письменный благодаря посредничеству 
канцелярского языка Великого княжества Литовского (далее ВКЛ) и/или «простой мовы» (см. ГАРБУль 2004a, 2004b, 2004c, 2005, 2008, 2010a, 2010b, 2011a, 2011b, 2014). Следует отметить, что среди лексем, факт заимствования которых из польского установлен нами впервые, доминируют внутриславянские дериваты. Как показывают наши материалы, и впредь список полонизмов, выявляемых в русском письменном языке XVI-XVII вв., будет пополняться в основном за счет заимствований такого рода.

В данной статье, которая продолжает серию публикаций (см. ГАРьУль 2004a, 2004b, 2004c, 2005, 2008, 2010a, 2010b, 2011a, 2011b), посвященных межславянским заимствованиям, обнаруженным в дипломатической корреспонденции по сношениям Московского государства (далее МГ) с западноевропейскими державами в XVII в., мы проследим историю еще десяти лексем и попытаемся доказать, что они были заимствованы из других славянских языков.

Взглядъ $[1]^{1}$ м. Точка зрения на кого-л., что-л., мнение о ком-л., чем-л.; оценка кого-л., чего-л. В составе сочетания мъти взглядъ 'принимать во внимание, учитывать что-л. (чье-л. мнение, соображение, позицию); считаться с кем-л., чем-л.’: «Однакоже на челобитье ихъ милостивы взглядъ маючи съ того крестного цълованья вызволивши на томъ переставаньђ, абы то войско вызволеное нигдъ людми своими зъ замковъ и остроговъ Московскихъ не осажало... и ничего непріятелского противъ... Его Королевской Милости... не зачинало» ${ }^{2}$ (ААЭ 3: 375 [246], 1634 г.).

Это существительное, имевшее общеславянское распространение, представляет собой безаффиксное образование от приставочного глагола, восходящего к праслав. *vbz-ględati 'смотреть, посматривать, поглядывать на кого-л., что-л.; присматриваться, приглядываться к кому-л., чему-л.', производному от праслав. *ględati, 1 л. ед. ч. *ględaje 'смотреть; всматриваться, вглядываться в кого-л., что-л.', 'присматривать за кем-л., чем-л., заботиться о ком-л., чем-л.', возникшему на основе более ранних форм *ględěti, *glęsti, и.-е. базой которых является *ghlend(h)- (корень *g'hel-: *ghel-) 'блестеть; мигать', 'смотреть, глядеть; бросить взгляд' (см. BORYś 2005: 722, ЧЕРныХ 1: 193, ФАСМЕР 1: 418, ЭСлРЯ 3: 87, ЭСлРЯ 4: 102-103, ЭССЯ 6: 122-123, 124).

Мы обнаружили взглядъ в указанном выше значении в дипломатической корреспонденции по сношениям МГ с Польшей и ВКЛ под 1634 г. На данный момент этот случай является наиболее ранней точно датированной фиксацией анализируемой лексемы в русской письменности. Во второй половине - последней четверти XVII в. это существительное отмечается в письменных источниках также в значении “направленность зрения на кого-л., что-л.;

\footnotetext{
${ }^{1}$ Здесь и далее цифрой в квадратных скобках указывается количество употреблений анализируемой лексемы в наших материалах.

2 Усечения начала и конца цитаты не отмечаются.

Studia Slavica Hung. 60, 2015
} 
взор,3 (СлРЯ XI-XVII вв. 2: 145, СОРЯ 2: 158). Согласно данным лексикографических источников, более широкое распространение взглядъ как в прямом, так и в переносном значении в русском языке получает только со второй половины XVIII в. (СлРЯ XVIII в. 3: 119-120). В обоих этих значениях исследуемое слово регулярно употреблялось в ХІХ в. (ДАль 1: 193), и в современном русском языке оно в значении 'направленность, устремленность глаз в сторону кого-л., чего-л.; взор' и 'точка зрения на кого-л., что-л.; оценка кого-л., чего-л.' входит в активный состав лексики (БАС 2: 508). Что касается устойчивого сочетания мъти взглядъ, в котором рассматриваемое существительное было выявлено впервые, то история его не прослеживается далее XVII в.

Наше внимание анализируемая лексема привлекла тем, что в русском письменном языке она впервые регистрируется в переносном значении, что наводит на мысль о возможной ее неисконности. Учитывая характер памятника, где взглядъ встречается впервые, можно предположить, что источником этого слова был польский язык. В старопольском языке wzglad первоначально (середина XV в.) фиксируется в значении 'widzenie, przywidzenie, widziadło, vīsum, ostentum', в последней четверти XV в. это существительное засвидетельствовано в значениях 'sposób odnoszenia się do kogoś, patrzenia, mŏdus spectāndi' и 'liczenie się z kims, z czyimś zdaniem, pamięć o kimś, respectŭs, rātio', в том числе и в составе сочетания mуеcz wsglad 'respǐcĕre' (SłStp 10: 619). В двух последних значениях wzglad бытовало в польском языке на протяжении XVI-XIX вв. (RECZEK 1968: 596, SłP XVII, LindE 6: 671, SłW 2: 205, KARŁOWICZ 7: 1135). И в словаре, отражающем современный польский язык, это существительное представлено в значении 'branie czego (lub kogo) pod uwagę, pamięć na kogo, na co, oględanie się, uważanie na со', в котором оно до сих пор употребляется в составе сочетания mieć wzglad na co, na kogo 'liczyć się z czym, z kim, brać kogo pod uwagę, pamiętać o czym' (SłJP 10: 357-358).

В актовом языке ВКЛ слово взглядъ, как и в русской письменности, впервые отмечается в составе устойчивого сочетания мъти (мети) взглядъ 'улічваць што-н., лічыцца з кім-н., чым-н.' (начало 90-х гг. XV в.), со второй половины 10-х гг. XVI в. это слово регистрируется и в свободном употреблении в значении 'пункт погляду, думка, пазіцыя' 4 , под которым в исторических словарях белорусского и украинского языков помещают рассматриваемое нами сочетание (ср. ГСБМ 3: 190, СУМ 4: 17-18). В анализируемом значении, в том числе и в составе указанного выше устойчивого сочетания, взглядъ бытовало в деловой письменности ВКЛ и текстах на «простой мове» до второй четверти XVIII в. (Тимченко 1: 96-97). Далее этого времени судьба лексемы взглядъ и сочетания мътии взглядъ ни для белорусского, ни для украинского языка не прослеживается.

\footnotetext{
${ }^{3} \mathrm{O}$ времени создания памятников, в которых взглядъ впервые было обнаружено в этом значении, см. ДмитРИЕВ 1969: 209, ДмитриЕВ 1972: 28-29.

${ }^{4}$ В значении 'позірк' это слово засвидетельствовано только с 80-х гг. XVI в. (ГСБМ 3: 189-190).
} 
Сопоставление приведенной выше информации, на наш взгляд, дает основания считать, что источником анализируемой лексемы в восточнославянских языках является польский, о чем свидетельствуют хронологические данные, характер памятников, на которые приходятся наиболее ранние фиксации, а также появление слова в первых сначала в переносном значении. Кроме того, заимствование в восточнославянские языки из польского подтверждается и тем, что в одном из исторических словарей украинского языка взглядъ в интересующем нас значении снабжено пометой «Пл.» (Тимченко 1: 96). В русский письменный язык XVII в. мъти взглядъ, вероятнее всего, проникло благодаря актовому языку ВКЛ.

Учитывая то, что взглядъ как в прямом, так и в переносном значении встречается в русских письменных источниках XVII в. спорадически, эти употребления надо рассматривать как предысторию слова в русском языке.

Выполняти [1] несов. Осуществлять, совершать; исполнять что-л.: «Но тотъ силникъ моі і обидитель... толь многую свою злобу выполняючи, і моего добра мне отдати не хотячи, учиниль мне в дву главизнахъ іли пунктахъ великие убытки: первое, какъ увезъ онъ отъ меня... то мое добро» (РИБ 15: 313 [136], 1651 г.).

Анализируемая лексема, вероятнее всего, образована путем суффиксации от префиксального глагола, восходящего к имеющему общеславянское распространение и точные соответствия в балтийских языках праслав. *pblniti 'делать полным, наполнять, заполнять', производному от прилагательного *pblnъ $(j b)$ 'наполненный, заполненный', 'целый; полный, совершенный' < и.-е. *pl-no-s 'полный; наполненный, заполненный', от и.-е. корня *pel- : *pl- 'лить, наливать', 'сыпать, насыпать', 'наполнять' (см. BoRYś 2005: 420421, BRÜCKNER 1974: 402, FRAENKEL 1: 591-592, МACHEK 1971: 461, ФACMEP 3: 312).

В русской письменности этот глагол спорадически отмечается в деловых документах середины XVII в. (1650 г., 1651 г.), один из которых отражает отношения МГ с Польшей и ВКЛ (СлРЯ XI-XVII вв. 3: 236; см. также выше). Примечательно, что в семнадцатом столетии не зафиксировано употребление формы перфектива выполнити. В источниках XVIII в. представлены формы обоих видов, причем в историческом словаре выполнить/выполнять 'исполнить, совершить, осуществить' снабжено пометой «слово, расширившее употребление» (СлРЯ XVIII в. 5: 6). В этом значении анализируемый глагол бытовал также в русском языке XIX-XX вв. и активно употребляется до сих пор (ДАль 1: 307, БАС 3: 513).

По мнению составителей одного из этимологических словарей русского языка, лексема выполнить является собственно русской (см. ЭСлРЯ 3: 228), по всей вероятности, данное утверждение относится и к производной от нее форме имперфектива. Однако, на наш взгляд, приведенная выше информация позволяет предположить заимствование, источником которого мог быть польский язык. 
В старопольских памятниках wypetnić 'wykonać coś, dokonać czegoś (nakazanego, poleconego), doprowadzić do skutku, dokończyć' известно с середины XV в., a wypetniać 'wykonywać coś nakazanego' - с конца того же столетия (SłStp 10: 516). В интересующем нас значении как перфектив, так и имперфектив бытовали в польском языке на протяжении XVI-XIX вв. (LINDE 6: 553, SłP XVII, KARŁOWICZ 7: 963-964). В словаре современного польского языка также регистрируется wypetniać в значении 'wykonywać co, wywiązywać się z czego; spełniać (zwykle: obowiązek, zadanie)' (SłJP 10: 144).

В актовом языке ВКЛ лексема выполняти засвидетельствована с начала XVI в. в значении 'дапаўняць, папаўняць, запаўняць (да пэўнай нормы), рабіць поўным', а с 50-60-х гг. того же столетия - и в значении 'выконваць; здзяйсняць, ажыццяўляць', в котором она наблюдалась в деловых документах, а также в текстах на «простой мове» и в XVII в. (ГСБМ 6: 25, СУМ 5: 249, Тимченко 1: 149). Для белорусского языка история глагола выполняти за пределами XVII в. не прослеживается. В украинском языке эта лексема в форме виповняти в интересующем нас значении продолжала употребляться в XVIII-XIX вв. (ГрінчЕнко 1: 178). В словаре современного украинского языка виповняти 'виконувати що-н.' уже сопровождается пометой «діал.» (ВТC 2005: 145). Заметим, что наиболее ранние фиксации выполняти в анализируемом значении отмечаются в деловых документах и текстах на «простой мове», язык которых в значительной степени полонизирован (ГСБМ 6: 25, СУМ 5: 249). Это дает определенные основания для предположения о возможном семантическом калькировании с польского, поскольку сама исследуемая лексема в памятниках ВКЛ регистрируется с начала XVI в.

Представленные выше факты из истории выполняти 'осуществлять, совершать; исполнять что-л.' в восточнославянских языках и wypetniać 'то же' в польском, по нашему мнению, подтверждают выдвинутое ранее предположение о заимствовании в восточнославянские языки из польского, во всяком случае, эти данные не исключают такой возможности. При этом проникновению анализируемого глагола в русский письменный язык XVII в., очевидно, способствовали канцелярский язык ВКЛ и «простая мова».

Высвобожати [1] несов. Избавлять от неволи, чьей-л. власти и т. п.; освобождать: «Да и иныхъ нашихъ бъдныхъ Москвитиновъ... съ заключенья невинного... высвобожать... не забывайте» (ДАИ 3: 262 [73], 1650-1653 гг.).

Этот глагол образован путем суффиксации от формы перфектива, представляющего собой, видимо, префиксально-суффиксальное производное от прилагательного, восходящего к имеющему общеславянские распространение праслав. *svobodb: *svoboda: *sveboda 'независимость, самостоятельность; воля’, образованию с редким суффиксом *-odb : *-oda от прилагательного *svobr: *svebr 'принадлежащий к своему племени, живущий на собст-

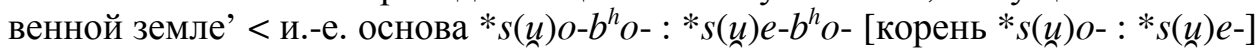
'свой, собственный' (см. BRÜCKNER 1974: 528, BORYŚ 2005: 589, ПРеОБРАЖЕНСКИй 2: 262-263, ФАСМЕР 3: 582-583, ЧЕРнЫХ 2: 148). 
Впервые высвобожати отмечается в середине 10-х гг. XVII в. и в письменных источниках этого столетия представлено единичными употреблениями только в дипломатических документах по сношениям МГ с Польшей и ВКЛ (СлРЯ XI-XVII вв. 3: 245; см. также выше). В лексикографических источниках, регистрирующих русский язык XVIII-XIX вв., имперфектив в интересующем нас значении фиксируется только в форме высвобождать (СлРЯ XVIII в. 5: 25, ДАль 1: 312). В словаре современного русского языка высвобождать в значении 'избавлять от неволи, чьей-л. власти и т. п.; освобождать' снабжено пометой «устаревающее», тогда как в значении 'избавлять от занятий (обычно тяжелых, неприятных и т. п.); освобождаться для иной деятельности' этот глагол входит в активный состав лексики (БАС 3: 556).

Учитывая характер памятников, в которых высвобожати встречалось в русском языке в XVII в., а также то, что однокоренные ему слова высвободити, высвободитися, высвобоженье считаются заимствованиями из польского (см. КоснмаN 1967: 151, WiткоWSкі 2006: 29, ГАРБУль 2004a: 37-38, 40), можно предположить, что и анализируемое нами слово попало в русский язык из того же источника. Для того, чтобы подтвердить или опровергнуть данную гипотезу, обратимся к истории соответствующей лексемы в польском языке.

В старопольском языке с конца XV в. известен перфектив wyświebodzić 'uczynić wolnym (od czyichś pretensji)', a c 60-х гг. XVI в. - имперфектив wyświebadzać 'wybawiać, uwalniać', который в формах wyswabadzać, wyswoba$d z a c ́$, wyswobodzać бытовал и в XVII-XIX вв. (RECZEK 1968: 591, LINDE 6: 619, KARŁOWICZ 7: 1054). В словаре современного польского языка wyswobadzać, wyswabadzać (rzadziej) также фиксируется в интересующем нас значении (SłJP 10: 266).

В письменности ВКЛ единичное употребление высвобожати 'вызваляць' засвидетельствовано уже во второй половине 10-х гг. XVI в., регулярно этот глагол наблюдается с 70-80-х гг. того же столетия в деловых актах и текстах на «простой мове» (ГСБМ 6: 96-97, СУМ 6: 37). Для украинского языка судьба анализируемой лексемы далее XVII века не прослеживается. В белорусском языке высвобожаць 'освобождать откуда' употреблялось еще в XIX в. (Носович 1870: 94). В лексикографических источниках, регистрирующих белорусский язык XX в., этот глагол уже не представлен.

Анализ истории исследуемого глагола в восточнославянских языках и польском позволяет сделать предположение, что в русский язык он мог проникнуть как из письменности ВКЛ, поскольку там выявлена наиболее ранняя его фиксация, так и из польского языка, где это слово имеет более длительную историю. Последнее обстоятельство могло способствовать тому, что польский язык, даже если он не был источником заимствования, поддерживал употребление высвобожати в русской письменности XVII-XVIII вв. В любом случае мы допускаем бо́льшую вероятность межславянского заимствования, нежели самостоятельного образования рассматриваемой лексемы в русском языке.

Studia Slavica Hung. 60, 2015 
Дал(ь)ший [1] прил. Дальнейший; последующий, будущий: «А городъ Смоленескъ, со всими уъздами и волостями своими, зоставаеть при Государствђ Московскомъ, до далшихъ намовъ и постановенья становъ Коруны Полскіе... съ послы Государства Московского о томъ...» (АИ 2: 389 [325], 1611 г.).

Анализируемая лексема представляет собой форму сравнительной степени от прилагательного, имеющего общеславянское распространение и восходящего к праслав. *dalekb(jb) 'отдаленный, далекий; дальний', образованному с помощью суффикса *-ekb $\left(<*_{-}-k b\right)$ от *dal'e 'далее, дальше', *dalb 'даль, большое расстояние, отдаленность'; последнее является спорным в этимологическом отношении образованием без и.-е. соответствий (см. BORYŚ 2005: 108, ФАСмЕР 1: 483, ЧЕРныХ 1: 231, ЭССЯ 4: 184-185, 186-187).

В русской письменности единичное употребление дальщий 'будущий' встречается уже в XVI в. в переводном с польского языка памятнике «Назиратель» (СОРЯ 5: 39). Мы обнаружили далиий в дипломатическом документе, отражающем контакты МГ с Польшей и ВКЛ в середине первой четверти XVII в. В словаре, регистрирующем русский язык XVIII в., дальший 'дальнейший’ представлено единственной иллюстрацией, датируемой 1731 годом, в сопровождении пометы «слово, выпавшее из употребления» (СлРЯ XVIII в. 6: 28). Таким образом, судьба рассматриваемого прилагательного в русском языке не прослеживается далее первой трети XVIII в.

История анализируемой лексемы в русском языке (характер памятников, в которых она наблюдалась, а также непродолжительность бытования в русской письменности) наводит на мысль о возможном заимствовании из польского языка. В старопольском языке dalszy 'późniejszy, postěrior' известно с 10-20-х гг. XV века (SłStp 2: 20). В значении 'późniejszy; następny' рассматриваемое прилагательное фиксировалось в письменности на протяжении XVI-XIX вв. (SłP XVI 4: 465, SłPaska 1: 124, LINDE 1: 408, KARŁOWICZ 1: 424), и в словаре современного польского языка оно представлено в том же значении (SłJP 2: 13).

В актовом языке ВКЛ второй половины XV в. (1462 г.) засвидетельствовано единичное употребление далшїи '(у часовому відношенні) пізніший, дальший’ в документе, отражающем отношения с Польшей (ССМ 1: 277). Затем, с 40-50-х гг. XVI в., дальший, далший, дальшый, далшый регистрируется в значении 'больш позні', а с 60-70-х гг. того же столетия - в значении 'далейшы, наступны', в которых оно бытовало и в XVII в. (ГСБМ 7: 236, 237, СУМ 7: 169-170). В белорусском языке история рассматриваемого прилагательного в анализируемом значении не прослеживается далее XVII века, ${ }^{5}$ a в украинском языке дальший в этом значении употреблялось в XVIII-XX вв. и в настоящее время входит в активный состав лексики (ГРінченко 1: 357, BTC 2005: 272-273).

\footnotetext{
${ }^{5}$ В значении ‘дальні, далейшы’ дальшы употребляется до сих пор (ТСБМ 2: 128).
} 
Приведенная выше информация об истории dalszy в польском и дальший в восточнославянских языках, на наш взгляд, позволяет говорить о том, что в последних исследуемое прилагательное является полонизмом, который в русскую письменность проник через посредничество актового языка ВКЛ.

Доведенье [1] c. Действие по глаг. довести в значении 'представить доказательства, доказать, засвидетельствовать': «И послы говорили: уличенья и доведенья с королевина величества стороны никакова не было... чтобъ де тьхъ досадныхъ слов впредь не поминать и не памятовать» (Якуьов 1897: 246, 1649 г.).

Это существительное образовано суффиксальным способом от префиксального глагола, восходящего к имеющему общеславянское распространение и ближайшие родственные соответствия в ирландском и балтийских языках праслав. *vesti, 1 л. ед. ч. *vedo ‘вести’ < и.-е. глагольный корень *ued(h)-, 'вести', 'жениться' (см. BRÜCKNER 1974: 619, BORYŚ 2005: 697, ФACMEP 1: 284, ЧЕРных 1: 146, ЭСлРЯ 3: 74-75).

По данным исторического словаря русского языка, анализируемая лексема в значениях: действие по глаголу довести 'привести осуществление чего-л. к какому-л. пределу' и 'привести в какое-л. состояние, положение' известна в памятниках с 60-80-х гг. XVIII века (СлРЯ XVIII в. 6: 165, 166). В толковом словаре первой четверти XIX в. это слово представлено следующим образом: «Доведеніе. Дъйствиїе доведшаго» (САР 2: 110). Лексема доведенье, доведение приводится также в словарях, регистрирующих русский язык XIX - начала XXI вв., как обозначение действия по ряду значений глагола довести (ДАль 1: 448, БАС 5: 168), но в интересующем нас значении это существительное пока не засвидетельствовано в русских лексикографических источниках. Таким образом, обнаруженное нами в дипломатическом документе по сношениям МГ со Швецией, где затрагиваются также отношения первого субъекта с Польшей и ВКЛ, употребление доведенье является наиболее ранней и на данный момент единственной фиксацией этого слова в русской письменности в рассматриваемом значении, хотя уже в деловых памятниках XV в. отмечается мотивирующий глагол довести 'представить доказательства вины кого-л.', получивший широкое распространение со второй половины XVI в. (СлРЯ XI-XVII вв. 4: 274-275, СОРЯ 5: 239).

Характер источника, в котором существительное доведенье в анализируемом значении выявлено в XVII веке, и история слова наводят на мысль о его неисконности в русском языке. В данном случае мы, вероятнее всего, имеем дело с межславянским заимствованием. Так, в старопольском языке dowiedzenie, dowiedzienie 'udowodnienie, uzasadnienie, poparcie dowodami, wykazanie' известно со второй половины 30-х гг. XV в. (SłStp 2: 168). В этом значении данное слово отмечалось и в XVI в., причем с 30-х гг. XVI в. параллельно с ним в том же значении используется существительное dowodzenie, образованное от имперфектива dowodzić (SłP XVI 5: 523, 541). C XVIII века 
в польском языке начинает доминировать dowodzenie (LINDE 1: 520, SłW 1: 249), но в словарях, отражающих польский язык XIX-XX вв., представлены обе формы (KARŁOWICZ 1: 541, 542, SłJP 2: 329, 331, ISłSJP).

В канцелярском языке ВКЛ со второй половины 30-х гг. XVI в. в интересующем нас значении отмечается доведенье (ГСБМ 8: 167), наряду с которым со второй половины XVI в. в том же значении регистрируется производное от имперфектива существительное довоженье (ГСБМ 8: 179, СУМ 8: 75, Тимченко 1: 214), получившее в письменности ВКЛ, как и в польском языке, более широкое распространение, чем доведенье. Следует заметить, что как доведенье, так и довоженье засвидетельствованы в деловых документах, язык которых в значительной степени насыщен полонизмами. Для белорусского языка судьба рассматриваемого существительного в анализируемом значении далее XVII в. не прослеживается. В словаре, отражающем украинский язык XVIII-XIX вв., регистрируется только лексема дово́дження 'доказательство, доказываніе' (Грінченко 1: 404). В современном украинском языке дове́дення употребляется в значении 'логічна форма встановлення істинності будь-якого судження на підставі інших суджень, істинність яких перевірена практикою', а дово́дження - как обозначение действия по глаголу дове́сти, дово́дити 'підтверджувати істинність, правильність чого-н. фактами, незаперечними доказами; доказувати’ (ВТС 2005: 309, 310).

Сопоставление приведенных выше данных, как нам представляется, дает определенные основания для вывода о том, что в письменность ВКЛ доведенье и довоженье проникли из польского, а затем, по-видимому, через посредничество канцелярского языка ВКЛ в середине XVII в. доведенье попало в дипломатическую корреспонденцию МГ. Дополнительным подтверждением того, что доведенье в анализируемом значении является полонизмом в русском письменном языке XVII в., может быть то, что семантическими полонизмами считаются однокоренные слова доводъ 'свидетельство, доказательство, подтверждение; аргумент' (см. Брицын 1965: 138, КоснмаN 1971: 51-53, Kochman 1972: 44, Kochman 1975a: 55-56, KосHмAn 1975b: 26, WitкоwSKi 1992: 265, WIткOWSKI 2006: 45) и доводити 'представлять доказательства, доказывать; аргументировать' (см. Брицын 1965: 135-137, КоснмаN 1971: 51-53, KochmAN 1975a: 55-56, WiтKOWSKI 1992: 265, WiтKOWSKI 2006: 45).

Догажати [1] несов. Угождать кому-л., удовлетворять что-л., кого-л.; заботиться, беспокоиться о ком-Л., чем-л.: «Что о поляках тех не надобно жалети, что казаком на море заборонили, не зделали того от истинного сердца противу нам, но чтоб покою своему догажали, не хотя войны имети...» (ВУР 3: 344 [179], 1653 г.).

Анализируемый глагол является формой имперфектива к догодити (см. ниже о его происхождении).

До сих пор считалось, что наиболее ранняя фиксация догажати в русской письменности относится к концу первого десятилетия XVIII в. (СлРЯ 
XVIII в. 6: 174), однако наши данные позволяют более чем на полстолетия передвинуть нижнюю границу хронологии этой лексемы. Уже в лексикографическом источнике, регистрирующем русский язык XVIII в., догожати, догажати снабжено пометами «новое слово, в XVIII в. вышедшее из употребления» и «укр. догоджати кому-чему» (СлРЯ XVIII в. 6: 174). Далее, в XIX-XX вв., употребление догожать 'угождать' прослеживается только в диалектах западных и южных губерний (областей) России (ДАль 1: 450, СРНГ 8: 88).

Итак, догажати, догожати представляет собой несомненное межславянское заимствование в русском языке, причем характер памятника, где впервые отмечен этот глагол, позволяет установить как язык-донор, так и язык-посредник. Так, в польском языке, который, по нашему мнению, является источником заимствования, dogadzać 'zadowalać kogoś, czynić dobrze komu, dbać o kogoś, o coś; ustępować komuś, liczyć się z kim; wysługiwać się, przypochlebiać się komuś' известно со второй половины 70-х гг. XVI в. (RECZEK 1968: 68, SłP XVI 5: 236-237) и бытовало в этом значении на протяжении XVII-XIX вв. (LINDE 1: 461-462, KARŁOWICZ 1: 484), употребляется это слово и в современном польском языке (SłJP 2: 196).

B памятниках ВКЛ единичное употребление догажати, догожати 'дагаджаць, задавальняць, спрыяць' засвидетельствовано в конце 70-х гг. XVI в., более регулярно анализируемый глагол наблюдается с конца 80-х гг. того же столетия (ГСБМ 8: 189-190, СУМ 8: 81). Следует заметить, что в письменности ВКЛ форма имперфектива встречается раньше формы перфектива догодити (см. о нем ниже), что может свидетельствовать о неисконности здесь первой формы и о заимствовании ее из польского языка. С конца XVI - начала XVII вв. рассматриваемая лексема прочно закрепилась в лексическом составе белорусского (дагаджаиь) и украинского (догожати, догоджати $)^{6}$ языков и бытует в них до настоящего времени (Носович 1870: 137, ТСБМ 2: 112, ГРінченКО 1: 407, ВТС 2005: 311).

Догодити [1] сов. Угодить, услужить кому-л.: «И мы... пришли для добра, покою и тишины того великого и преславного господарства Московского... такъ и в той прозбе вашой вам догодить, будет ли на то всемогущого... Бога воля» (Сб. РИО 142: 75, 1610 г.).

Эта лексема представляет собой сложение, имеющих общеславянское распространение и восходящих к праславянскому языку, приставки *do и глагола *goditi, 1 л. ед. ч. *godjg 'делать что-л. в благоприятное или удобное время, впопад', 'попадать' > 'угождать, удовлетворять', связанного с именем *godb 'благоприятное, подходящее, удобное время, момент', с и.-е. базой * ghadh- 'объединять, быть связанным', 'соответствовать, быть подходящим' (см. ЭССЯ 5: 51, ЭССЯ 6: 188-190, 191-192).

${ }^{6}$ В XIX в. употреблялись обе формы, в современном украинском языке - только последняя форма.

Studia Slavica Hung. 60, 2015 
До сих пор глагол догодить 'угодить, сделать кому-л. приятное' отмечался только в XIX-XX вв. в говорах Смоленской, Орловской, Курской, Псковской, Новгородской губерний (областей) (СРНГ 8: 88). Мы обнаружили это слово в дипломатической корреспонденции по сношениям МГ с Польшей и ВКЛ. Догодити, как и догажати, догожати, попало в русский письменный язык первой четверти XVII в., очевидно, из польского. В польских письменных источниках dogodzić 'zadowolić kogoś; przysłużyć się komuś, zrobić coś dobrego, przyjemnego, pomóc komuś, pójść na rękę; ulec komuś' известно со второй половины 70-х гг. XVI в. (RECZEK 1968: 69, SłP XVI 5: 241, LINDE 1: 461-462, KARŁOWICZ 1: 484) и активно употребляется в этом значении до настоящего времени (SłJP 2: 197).

C 80-х гг. XVI в. догодити 'дагадзіць, задаволіць' встречается в памятниках ВКЛ, причем первоначально в текстах, язык которых насыщен полонизмами (ГСБМ 8: 188-189, СУМ 8: 81). В указанном выше значении данная лексема бытовала в белорусском (дагадзіиь) и украинском (догодити) языках XVIII-XIX вв. (Носович 1870: 137, Грінченко 1: 407), она вХодит в активный лексический запас этих языков и сейчас (ТСБМ 2: 112, ВТС 2005: 311).

История догодити в письменности ВКЛ, а также характер памятника, в котором этот глагол был зафиксирован нами, дают основание считать, что в приказный язык МГ он мог проникнуть благодаря посредничеству актового языка ВКЛ и /или «простой мовы».

Додавати [2] несов. Давать что-л. недостающее; прибавлять, добавлять к уже имеющемуся: «Въ тъ поры многихъ кормовъ не додавали» (ДРВ 4: 106, 1602 г.). «Просятъ у Короля нашего, чтобъ ихъ отъ непріятеля Московского боронилъ и оружія додавалъ» (ПДС 3: 663, 1656 г.).

Анализируемая лексема, вероятнее всего, представляет собой сложение имеющих общеславянское распространение и соответствия в других индоевропейских языках и восходящих к праславянскому языку префикса $* d o$ - и многократного глагола *davati : dajati, 1 л. ед. ч. *davajo : *dajo 'давать', формы имперфектива, соотносительной с *dati, 1 л. ед. ч. *damb 'дать' < и.-е. корень *do--u- : *də-u- 'дать' (см. BoRYś 2005: 110, ЧЕРныХ 1: 232, ФАСмEP 1: 480, 485, ЭССЯ 4: 183-184, 194-195, 197-198).

Наиболее ранние употребления додавати регистрируются в последней четверти XVI в. в переводном с польского языка памятнике «Назиратель» и дипломатическом документе 1583 г. по сношениям МГ с Англией (СОРЯ 5: 250, СлРЯ XI-XVII вв. 4: 283). Мы обнаружили этот глагол в дипломатической переписке, отражающей контакты МГ с Польшей и ВКЛ. Эта лексема бытовала и в русском языке в XVIII-XIX вв. (СлРЯ XVIII в. 6: 175, Даль 1: 451), она активно употребляется и в современном русском языке (БАС 5: 188).

Характер памятников, где додавати на первых порах наблюдалось в русской письменности, дает определенные основания для предположения о возможности в данном случае межславянского заимствования. В связи с этим 
обратимся к истории анализируемого слова в тех славянских языках, с которыми у русского языка во второй половине XVI - первой половине XVII вв. были наиболее тесные контакты.

Так, в старопольском языке dodawać 'dawać, dostarczać' известно с конца XIV - начала XV вв. (SłStp 2: 107-108). C 60-х гг. XVI в. этот глагол отмечается также в значении 'przydawać, dawać więcej, dokładać do tego, co się posiada', в котором он продолжал употребляться в XVII-XX вв. и бытует в современном польском языке (SłP XVI 5: 231, SłPaska 1: 150, LiNDE 1: 458, KARŁOWICZ 1: 482, SłJP 2: 191).

В письменности ВКЛ лексема додавати первоначально (вторая половина 10-х гг. XVI в.) засвидетельствована в значении 'даваць', а с 60-70-х гг. того же столетия она наблюдается и в интересующем нас значении 'дапаўняць тое, чаго не хапае' (ГСБМ 8: 192, СУМ 8: 182), в котором это слово регистрируется в лексикографических источниках белорусского (дадаваџь) и украинского (додавати) языков до сих пор (Носович 1870: 137, ТСБМ 2: 114, ГРІнчЕНКО 1: 408-409, ВТС 2005: 311).

Учитывая приведенные выше данные, по нашему мнению, не следует исключать возможности заимствования глагола додавати в восточнославянские языки из польского. При этом в русский письменный язык последней четверти XVI - начала XVII вв. он мог попасть благодаря посредничеству канцелярского языка ВКЛ и «простой мовы».

Доложити [2] сов. Добавить, прибавить недостающее; дополнить: «А чего будет в рускомъ Судебънике къ укрепленью суда и права не доложоно, и тое въсе... поправить и доложить волно, советовав з бояры и зъ землею» (Сб. РИО 142: 66, 1610 г.).

Это слово является префиксальным производным от глагола, имеющего общеславянское распространение и восходящего к праслав. *ložiti $(<*$ logiti), 1 л. ед. ч. *lož $(<* \operatorname{logj} q)$ 'класть', который, по-видимому, представляет собой отыменное образование на -iti с корневым вокализмом -о- от праслав. *logъ < и.-е. корень *logh- 'место лежания; засада', 'могила' (см. ЭССЯ 9: 152-153, ЭССЯ 15: 248-249, ЭССЯ 16: 127-128).

В анализируемом нами значении доложити известно в русской письменности с начала XVII в. ${ }^{7}$ и в этом столетии регистрировалось только в дипломатической корреспонденции по сношениям МГ с Польшей и ВКЛ (см. выше, а также СлРЯ XI-XVII вв. 4: 305). В рассматриваемом значении эта лексема представлена в словаре, отражающем русский язык XVIII в., однако в этот период она еще не имела широкого распространения (СлРЯ XVIII в. 6: 199). В лексикографических источниках, регистрирующих словарный состав русского языка XIX - начала XXI вв., доложсить фиксируется в значении 'положить дополнительно, до определенного предела; добавить' (БАС 5: 241).

\footnotetext{
${ }^{7}$ Омонимичное по отношению к нему слово доложити 'довести до сведения, доложить' в древнерусском языке - уже в XII-XIII вв. (СРЕзнЕВский 1: 695, СлДРЯ 3: 40).

Studia Slavica Hung. 60, 2015
} 
История глагола доложити 'добавить, прибавить недостающее; дополнить' наводит на мысль о неисконности его в русском языке. При этом наиболее вероятным источником этого слова в русской письменности XVII в. мог быть польский язык. В старопольском языке dołożyć 'dodać, przyczynić, adděre, appōnĕre' засвидетельствовано с середины XV в. (SłStp 2: 124). Эта лексема в значении 'dodać, przyłożyć, dopełnić, uzupełnić, dołączyć, dorzucić' отмечалась в письменных источниках и на протяжении XVI-XIX вв. (SłP XVI 5: 300, SłPaska 1: 153, LindE 1: 479, KARŁOWICZ 1: 501). В современном польском языке dotożyć также представлено в интересующем нас значении (SłJP 2: 211).

В памятниках ВКЛ лексема доложити, доложыти фиксируется с начала XVI в. именно в интересующем нас значении 'дадаць, дабавіць ў дадатак да чаго-н.', в котором она бытовала в канцелярском языке и в текстах на «простой мове» и в XVII в. (ГСБМ 8: 261, СУМ 8: 82). В этом значении глагол употреблялся в украинском языке XVIII-XIX вв. (см. Гринченко 1: 417). Согласно данным лексикографических источников, далажіщь 'палажыць дадаткова; дадаць, дакласці' входит в активный словарный запас современного белорусского языка (ТСБМ 2: 124), тогда как в украинском языке доложити в том же значении является принадлежностью разговорного стиля речи и редко употребляемым словом (ВТС 2005: 313, 315).

Исходя из приведенной выше информации, на наш взгляд, есть основания полагать, что в восточнославянские языки доложити в анализируемом значении было заимствовано из польского. При этом в русский письменный язык оно проникло, очевидно, через посредничество актового языка ВКЛ и /или «простой мовы».

Допомогати [1] несов. Помогать, оказывать помощь кому-л., чему-л. кем-Л., чем-л., поддерживать кого-л.; действовать совместно с кем-л.: «Наступит ли который неприятель на Московское господаръство, или на Польшчу, или на Литву, и противъ того стаяти и допомогать обоими господаръствы» (Сб. РИО 142: 66, 1610 г.).

Рассматриваемая лексема, вероятнее всего, образована путем префиксации от приставочного глагола (праслав. *pomagati 'помогать', имперфектив к *pomogti 'помочь'), восходящего к праслав. *mogti, 1 л. ед. ч. *moge (многократный подвид глагола - *magati) 'быть в состоянии, мочь', имеющему общеславянское распространение и достоверные и надежные соответствия в балтийских и германских языках, и.-е. базой которого является *mägh'быть в состоянии; быть в силах', 'помогать' (см. BORYŚ 2005: 338, REJZEK 2001: 486, ЕСУМ 4: 510, ЧЕРНЫХ 1: 546, ПРЕОБРАЖЕНСКИЙ 1: 563-564, ФАСМЕР 2: 635-636, ЭССЯ 19: 107-111).

В русской письменности это слово до сих пор не фиксировалось, мы обнаружили его в дипломатическом документе по сношениям МГ с Польшей и ВКЛ в середине первой четверти XVII в. С середины 40-х гг. того же столетия в деловом языке регистрируется форма перфектива допомочь 'помочь, 
оказать помощь' (СОРЯ 5: 302), которую В. Витковский считает заимствованием из польского (WITKOWSKI 2006: 46). В русской лексикографии допомочь 'помочь, пособить, оказать помощь, пособіе для достиженья чего' представлено только у В. И. Даля (см. ДАль 1: 471). Судя по информации, которой мы располагаем о допомогати, форма имперфектива, как и форма перфектива, очевидно, является полонизмом.

Проследим историю dopomagać в польском языке: в старопольских источниках оно в значении 'iuvare, succurrěre' засвидетельствовано с 50-60-х гг. XV века (SłStp 2: 136-137). В значении 'pomagać, udzielać pomocy, wspierać w czym, przyczyniać się do czego' этот глагол отмечался и в памятниках XVI в. (SłP XVI 5: 370, 371). В текстах XVII в., наряду с указанным выше употреблением, dopomagać встречается также в значении 'współdziałać, brać w czym udział', в котором оно наблюдалось еще в XVIII в. (SłPaska 1: 159, LINDE 1: 493). В значении 'okazywać komu pomoc, wspierać kogo, przyczyniać się do czego' анализируемый глагол употребляется до настоящего времени, а в значении 'współdziałać, towarzyszyć, brać udział w czym' это слово в словаре, отражающем язык XIX в., имеет помету «mało używany» (KARŁowICZ 1: 515), a в словаре современного польского языка - помету «daw.» (SłJP 2: 266).

В актовом языке ВКЛ допомагати, допомогати 'допомагати' спорадически регистрируется во второй половине XV века (1457 г., 1480 г., 1481 г.) в документах, язык которых насыщен полонизмами, более регулярно - с начала XVI в., широкое распространение это слово получает во второй половине XVI-XVII вв. в деловых документах и текстах на «простой мове» (CCM 1: 318, ГСБМ 8: 299, СУМ 8: 131-132, Тимченко 1: 223). Рассматриваемый глагол в указанном значении активно употреблялся в белорусском (допомогащь) и украинском (допомагати) языках XVIII-XIX вв. (Носович 1870: 141, ГРінченко 1: 424) и бытует в современных белорусском (дапамагащь) и украинском (допомагати) языках (ТСБМ 2: 133, ВТС 2005: 319).

Подведем итог обзора истории анализируемой лексемы в восточнославянских языках и польском: в русском письменном языке XVII в. допомога$m u$, как и допомочи, вероятнее всего, является заимствованием из польского. В другие восточнославянские языки, учитывая хронологические данные и форму допомагати, этот глагол, очевидно, был заимствован из того же источника. В этом случае актовый язык ВКЛ и «простая мова» могли выступать в роли посредников в процессе заимствования в русский письменный язык XVII века.

Резюмируя результаты историко-этимологического анализа десяти лексем, представленных выше, можно сформулировать некоторые обобщающие выводы:

1. Исследование лексем, которые до сих пор не рассматривались с точки зрения их происхождения, показало, что, несмотря на общеславянское распространение и праславянскую древность их корнеслова и словообразовательных аффиксов, эти внутриславянские дериваты, вероятнее всего, являются не самостоятельными образованиями в русском языке, а межславянскими 
заимствованиями. Так, взглядъ, выполняти, дал(ь)ший, доведенье, догажати, догодити, додавати, доложити, допомогати в анализируемых значениях, по нашему мнению, являются полонизмами, а высвобожсати, очевидно, попало в русский письменный язык XVII в. из письменности ВКЛ.

2. Отметим явления фонетической субституции и акцентной адаптации перечисленных выше заимствований:

a) вокализм: $a>$ ' $a$ (wzglad - взглядъ), $e>o$ как рефлекс $b$ (wypetniać выполняти);

б) консонантизм: $d z>\nsim$ (wyswobadzać, wyswobodzać - высвобожати, dogadzać - догажати);

в) акцентуация: перемещение ударения с корня глагола (польский язык) на суффикс в восточнославянских языках в соответствии с акцентным типом соответствующих глаголов в этих языках.

3. В девяти случаях из десяти в роли активного посредника в польскорусских языковых контактах во второй половине XVI-XVII вв. выступали (выступала) деловая письменность ВКЛ и/или «простая мова», благодаря которым (которой) в русский письменный язык указанного периода проникли лексемы взглядъ, выполняти, дал(ь)ший, доведенье, догажати, догодити, додавати, доложсти, допомогати в исследуемых значениях.

4. Как известно, хронологический аспект исследования языковых контактов влияет на научное подтверждение факта заимствования (см. ГАРБУль 2009: 35-36, КувшиновА 2012: 108). При контактировании генетически родственных языков хронологические данные приобретают первостепенное значение, поскольку играют важную роль в установлении направления языкового влияния. Из этого следует, что необходимо скрупулезнейшим образом регистрировать все, в том числе и окказиональные, случаи заимствований, встречающиеся в памятниках письменности, поскольку именно эта информация позволяет в ряде случаев установить трудно уловимую миграцию отдельных слов из одного близкородственного языка в другой.

Наш материал позволяет внести некоторые уточнения и дополнения в хронологическую характеристику анализируемых лексем. Так, для лексем взглядъ и догажсати удревнение времени их появления в русской письменности составило более полувека, для лексемы доведенье - более столетия, для слова догодити - почти два с половиной столетия, а глагол допомогати зарегистрирован впервые.

5. Что касается дальнейшей судьбы представленных в публикации лексем в контактировавших языках, то в русском языке слова взгляд, ${ }^{8}$ выполнять, додавать, доложить 'положить дополнительно, до определенного предела; добавить ${ }^{9}$ входят в активный состав лексики до настоящего времени,

\footnotetext{
${ }^{8}$ Устойчивое сочетание, в составе которого эта лексема была обнаружена нами, является окказионализмом в русском письменном языке XVII в.

${ }^{9} \mathrm{~B}$ интересующем нас употреблении 'дополнить (текст, документ)' этот глагол в лексикографических источниках XX - начала XXI в. не представлен.
} 
высвобождать в анализируемом нами употреблении в современной русской лексикографии причисляется к устаревающим словам (БАС 3: 556), история прилагательного дал(ь)ший ограничивается первой третью XVIII в., глаголы догожать и догодить в XX веке отмечались только в говорах западных и южных областей России, а существительное доведенье в рассматриваемом значении и глагол допомогати следует отнести к окказионализмам в связи с тем, что они представлены единичными фиксациями только в русской письменности XVII в.

В других восточнославянских языках история анализируемых лексем такова: глаголы дагаджаць, дагадзіць, дадаващь, далажыць, дапамагащь до сих пор употребляются в современном белорусском языке, судьба же существительных взглядъ, доведенье, прилагательного дал(ь)щий в интересующем нас значении и глагола выполняти в белорусском языке не прослеживается далее XVII в., а глагола высвобожсаиь - далее XIX в.

В современном украинском языке в активный состав лексики входят лексемы дальший, доведення 'логічна форма встановлення істинності будь-якого судження на підставі інших суджень, істинність яких перевірена практикою', догоджати (в XIX в. также догожати), догодити, додавати, допомагати. Глагол доложити в интересующем нас значении бытует в разговорном стиле речи и относится к редко употребляемым словам, глагол виповняти в анализируемом значении отмечается только в диалектах. История глагола высвобожати в украинском языке ограничивается XVII в., а существительного взглядъ - первой четвертью XVIII в.

В польском языке все рассмотренные лексемы активно употребляются до настоящего времени. ${ }^{10}$

\section{Источники}

ААЭ = Акты , собранные в библиотеках и архивах Российской империи Археографическою экспедициею императорской Академии наук. Т. 3. Санкт-Петербург, 1836.

АИ = Акты исторические, собранные и изданные Археографическою комиссиею. Т. 2. Санкт-Петербург, 1841.

ВУР = Воссоединение Украины с Россией: Документы и материаль. Т. 3. Москва, 1953.

ДАИ = Дополнения к Актам историческим, собранным и изданным Археографическою комиссиею. Т. 3. Санкт-Петербург, 1848.

ДРВ = Древняя Российская вивлиофика. Изд. Н. Новиковым. Ч. 4. Москва, 1788.

ПДС = Памятники дипломатических сномений древней России с державами иностранными. Памятники дипломатических сночений с Римскою Империею. Т. 3. С 1632 по 1660 год. Санкт-Петербург, 1854.

${ }^{10}$ Глагол dopomagać в значении 'okazywać komu pomoc, wspierać kogo, przyczyniać się do czego' входит в активный лексический запас, а в значении 'współdziałać, towarzyszyć, brać udział w czym' он в современной польской лексикографии сопровождается пометой „daw.“ (SłJP 2: 266).

Studia Slavica Hung. 60, 2015 
РИБ = Русские акты Ревельского городского архива (1397-1689 гг.). Под ред. А. Барсукова. Русская историческая библиотека, издаваемая Археографическою комиссиею. Т. 15. Санкт-Петербург, 1894.

Сб. РИО = Памятники дипломатических сночений Московского государства с Польско-Литовским государством. Т. 5. (1609-1615 гг.) Сборник Русского исторического общества. Т. 142. Москва, 1913.

Якуьов 1897 = ЯкуБов К. Россия и Швеция в первой половине XVII в. Сборник материалов... касающихся истории взаимных отношений России и Швеции в 16161651 г2. Москва, 1897.

\section{Словари}

БАС = Большой академический словарь русского языка. Т. 1-23. Санкт-ПетербургМосква, 2004-2014.

ВТС 2005 = Великий тлумачальний словник сучасної украӥнської мови. Уклад. і ред. В. Т. Бусел. Київ, 2005.

ГРІнЧЕНКО = ГРІнЧЕНКО Б. Словарь украӥнської мови в чотирьох томах. Т. 1-4. Київ, 1996-1997.

ГСБМ = Гістарычны слоўнік беларускай мовы. Вып. 1-33. Мінск, 1982-2013.

ДАль = ДАЛь В. И. Толковый словарь живого великорусского языка. Т. 1-4. Москва, 1978-1980.

ЕСУМ = Етимологічний словник украӥнської мови. Т. 1-6. Київ, 1982-2002.

Носович 1870 = Носович И. Словарь белорусского наречия. Санкт-Петербург, 1870.

ПРЕОБРАЖЕНСКИЙ = ПРЕОБРАЖЕНСКИЙ А. Г. ЭТИмологический словарь русского яЗыка. Т. 1-2. Москва, 1959.

САР = Словарь Академии Российской, по азбучному порядку расположенный. Ч. 1-6. Санкт-Петербург, 1806-1822.

СлДРЯ = Словарь древнерусского языка (XI-XIV вв.). Т. 1-10. Москва, 1988-2013.

СлРЯ XI-XVII вв. = Словарь русского языка XI-XVII вв. Вып. 1-29. Москва, 19752011.

СлРЯ XVIII в. = Словарь русского языка XVIII века. Вып. 1-20. Санкт-Петербург, 1984-2013.

СОРЯ = Словарь обиходного русского языка Московской Руси XVI-XVII веков. Вып. 1-5. Санкт-Петербург, 2004-2013.

СРЕЗНЕВСКИЙ = СРЕЗНЕВСКИЙ И. И. Материаль для словаря древнерусского языка. Т. 1-3. Санкт-Петербург, 1893-1912.

СРНГ = Словарь русских народных говоров. Вып. 1-46. Москва-Санкт-Петербург, 1965-2013.

CСM = Словник староукраӥнської мови XIV-XV cm. Т. 1-2. Київ, 1977-1978.

СУМ = Словник української мови XVI - першої половини XVII cm. Вип. 1-15. Львів, 1994-2010.

Тимченко = Тимченко Є. К. Материали до словника писемної та книжної украӥнської мови XV-XVIII cm. Кн. 1-2. Київ-Нью-Йорк, 2002-2003.

ТСБМ = Тлумачальны слоуннік беларускай мовы. Т. 1-5. Мінск, 1977-1984.

ФАСМЕР = ФАСМЕР Макс: Этимологический словарь русского языка. Т. 1-4. Москва, 1964-1973.

ЧЕРнЫХ = ЧЕРНЫХ П. Я. Историко-этимологический словарь современного русского языка. Т. 1-2. Москва, 1999. 
ЭСлРЯ = Этимологический словарь русского языка. Вып. 1-10. Москва, 1963-2007. ЭССЯ = Этимологический словарь славянских языков. Вып. 1-39. Москва, 1974-2014.

BORYŚ 2005 = BORYŚ W. Stownik etymologiczny języka polskiego. Kraków, 2005.

BRÜCKNER 1974 = BRÜCKNER A. Stownik etymologiczny języka polskiego. Warszawa, 1974.

FRAENKEL = FRAENKEL E. Litauisches etymologisches Wörterbuch. Bd. 1-2. HeidelbergGöttingen, 1962-1965.

ISłSJP = Internetowy stownik synonimów języka polskiego online. http://synonim.net/.

KARŁOWICZ = KARŁOWICZ J., KRYŃSKI A., NIEDŹWIEDZKI W. (red.) Słownik języka polskiego. T. 1-8. Warszawa, 1900-1927.

LINDE = LinDE S. B. Stownik języka polskiego. T. 1-6. Lwów, 1854-1860.

MACHEK 1971 = MACHEK V. Etymologický slovník jazyka českého. Praha, 1971.

RECZEK 1968 = RECZEK S. Podręczny słownik dawnej polszczyzny. Wrocław-WarszawaKraków, 1968.

REJZEK 2001 = REJZEK J. Český etymologický slovník. Praha, 2001.

SłJP = Stownik języka polskiego. T. 1-11. Warszawa, 1958-1969.

SłP XVI = Stownik polszczyzny XVI wieku. T. 1-36. Wrocław-Warszawa-Kraków-Gdańsk, 1966-2012.

SłP XVII = Elektroniczny stownik języka polskiego XVII $i$ XVIII wieku. http://sxvii.pl.

SłPaska = Słownik języka Jana Chryzostoma Paska . T. 1-2. Wrocław-Warszawa-Kraków, 1965-1973.

SłStp = Stownik staropolski. T. 1-11. Warszawa, 1953-2002.

SłW = ZDANOWICZ A. i in. (red.) Stownik języka polskiego do podręcznego użytku. Cz. 1-2. Wilno, 1861.

WITKOWSKI 2006 = WITKOWSKI W. Nowy słownik zapożyczeń polskich w języku rosyjskim. Kraków, 2006.

\section{Литература}

БРИЦЫН 1965 = БРИЦЫН М. А. Из истории восточнославянской лексики. Киев, 1965.

ГАРБУЛЬ 2004а = ГАРБУЛЬ Л. К вопросу о межславянских лексических заимствованиях в русском приказном языке XVII века. Studia Slavica Hung. 49 (2004): 27-43.

ГАРБУЛЬ $2004 \mathrm{~b}=$ ГАРБУЛЬ Л. К истории некоторых полонизмов в русском языке. Respectus Philologicus 6 (2004): 45-55.

ГАРБУЛЬ $2004 \mathrm{c}=$ ГАРБУЛЬ Л. К вопросу о происхождении лексем жадность, заочно, заочный, заслуга, злость в русском языке. Slavistica Vilnensis 2004/2: 53-67.

ГАРБУль 2005 = ГАРБУЛЬ Л. Межславянские заимствования-полонизмы в русском приказном языке XVII в. Respectus Philologicus 8 (2005): 110-121.

ГАРБУЛЬ 2008 = ГАРБУЛЬ Л. История лексем затруднить, налгать, пограничье, родовитый в русском и других восточнославянских языках. Respectus Philologicus 13 (2008): 180-191.

ГАРБУЛЬ 2009 = ГАРБУЛЬ Л. Семантические полонизмы в русском приказном языке первой половины XVII века. Vilnius, 2009.

ГАРБУЛЬ 2010а = ГАРБУЛЬ Л. История лексем дознаться и заслышать в русском и других восточнославянских языках. Slavistica Vilnensis 2010/2: 140-148.

ГАРБУЛь $2010 \mathrm{~b}=$ ГАРБУль Л. Отражение результатов межславянских языковых контактов в русской деловой письменности первой половины XVII века (синхронный и диахронический аспекты) I. Respectus Philologicus 18 (2010): 179-190. 
ГАРБУЛь 2011a = ГАРБУЛь Л. Отражение результатов межславянских языковых контактов в русской деловой письменности первой половины XVII века (синхронный и диахронический аспекты) II. Respectus Philologicus 19 (2011): 168-178.

ГАРБУЛЬ $2011 \mathrm{~b}=$ ГАРБУЛЬ Л. К вопросу о межславянской миграции лексики (о происхождении некоторых слов в русском языке). В кн.: Русистика и компаративистика VI. Вильнюс, 2011. 191-201.

ГАРБУЛЬ 2014 = ГАРБУЛЬ Л. Лексические полонизмы в русском приказном языке первой половины XVII века. Vilnius, 2014.

ДмитриЕв $1969=$ ДмитриЕв Л. А. Первоначальный вид и время возникновения «Сказания о молодце и девице». В кн.: Трудь Отдела древнерусской литературы 24. Ленинград, 1969. 205-209.

ДмитРИЕВ 1972 = ДмитРИЕВ Л. А. Отрывок сборника пословиц XVII в. В кн.: Рукописное наследие Древней Руси. По материалам Пушкинского дома. Ленинград, 1972. 28-56.

ЗОЛТАН 2014 = ЗОЛТАН А. Interslavica. Исследования по межславянским языковым и культурным контактам. Москва, 2014.

КувшиновА 2012 = КувшиновА Н. М. Историко-лингвистический анализ немецких лексических заимствований в русском языке XVII-XVIII веков. Науковий часопис НПУ імені М. П. Драгоманова. Серія 9. Сучасні тендениії розвитку мов 8. Київ, 2012. 108-114.

KOCHMAN 1967 = KoCHMAN S. Polsko-rosyjskie kontakty językowe w zakresie stownictwa w XVII wieku. Wrocław-Warszawa-Kraków, 1967.

KoCHMAN 1971 = KochMAN S. Polonizmy w języku rosyjskiej korespondencji dyplomatycznej (1487-1571). Cz. I. Sprawozdania Opolskiego Towarzystwa Przyjaciół Nauk 7 (1971): 37-54.

KoCHMAN 1972 = KochMAN S. Wasilij Trediakowski w kręgu polskich wpływów językowych. Slavica Wratislaviensia III. Wrocław, 1972. 39-54.

Kochman 1975a = Kochman S. Polsko-rosyjskie stosunki językowe od XVI do XVIII w. Stownictwo. Opole, 1975.

Kochman 1975b = КоснмаN S. Латынь как источник польско-русских словесных калек. Zeszyty Naukowe Wyższej Szkoty Pedagogicznej w Opolu. Filologia Rosyjska 12 (1975): 19-27.

WITKOWSKI 1992 = WITKOWSKI W. Rosyjskie zapożyczenia semantyczne z języka polskiego. Z polskich studiów slawistycznych VIII. Warszawa, 1992. 263-270. 